\title{
Corporate Diversification and Firm Performance: Evidence from Asian Hotel Industry
}

\author{
Chai-Aun Ooi ${ }^{1}$, Chee-Wooi Hooy ${ }^{2}$, Ahmad Puad Mat Som ${ }^{3}$ \\ ${ }^{1,2}$ School of Management, Universiti Sains Malaysia, 11800, Penang, Malaysia \\ ${ }^{3}$ School of Housing, Building and Planning, Universiti Sains Malaysia, 11800, Penang, Malaysia
}

\begin{abstract}
The unstable environment of hotel industry which is driven by the fluctuation of tourism demand has motivated this study to look into the best diversification strategy for firm performance betterment. 42 hotel firms are investigated across 4 Asian economies, from year 2001 to 2012. Our results suggest that unrelated industrial diversification is the only alternative to improve hotel firm performance. Unrelated international diversification instead has a significant negative effect towards firm performance. Our results further show that board of directors implies a significant link to the relationship between diversification and firm performance, only in a crisis period.
\end{abstract}

\section{Introduction}

The introduction of herfindahl and entropy index which measure the degree of diversification enable scholars to further shed light on the issues of related and unrelated diversification, for instance the studies of [1-3]. Literature finds that the classification of related and unrelated diversification is a matter of firm performance. The classification is useful to distinguish the nature of the core industry and the diversified segments, for some of the diversified segments may have high correlation with the core business. The highly correlated diversified segments may have a similar target market, as well as the similar competition environment with the core business. It has two possible contradictory hypotheses could be made upon the benefits of related and unrelated diversification. On one hand, related diversification could enhance the efficiency of market synergy between each division. Related diversification also requires lesser cost of transferring of the firms' core capabilities to the other correlated divisions. On the other hand, unrelated diversification could minimize the risks of an unexpected crisis striking an industry or a country. In the context of hotel industry, it is unknown whether the premium of related diversification is more significant to improve the firm performance; or it is vice versa, of which the premium of risk minimization of unrelated diversification is more significant to influence firm performance, due to the highly unstable environment of the hotel industry.

Literature finds that human capital is important to moderate the effect of diversification on firm performance, as shown in the studies of [4] and [5]. It is because firms require talent and professional skills to oversee the entry into different markets and industries [6]. For a diversified firm which has to deal with external contingencies posed by foreign markets, the human capital in terms of specialized knowledge and experience is essential to reduce the uncertainties of diversification [7]. Also, [8] give the notion that greater human capital could facilitate a firm to recognize and exploit the embedded business opportunities, as well as helping in setting diversification strategy. Therefore, there are studies like [9] demonstrate that human capital could moderate the performance outcomes of 
industrial and international diversification. With that, this study even investigates whether the human capital of board of directors, the ultimate decision maker, could significantly moderate the effect of diversification on firm performance during a crisis period. The rationale of emphasizing the moderating role of board's human capital in the crisis period is because the board of directors involves closely in the firm's strategy formulation during the time of crisis [10]. The managers' bargaining power tends to be reduced during unstable environment, which enables the board to have less difficulty to request for strategic change. Therefore, it is worthy of research of the moderating role of board's human capital in the crisis period. In this study, the extent of the human capital in a boardroom is represented by the size of the board of directors.

\section{Literature Review}

\subsection{Industrial Diversification and International Diversification}

From theoretical points of view, internationalization theory promotes diversification by arguing that diversified firms can organize the activities internally between each division in order to develop and exploit firm-specific advantages in knowledge and products for better firm performance. [11] document that international diversification enables the firms to be more efficient in allocating resources in the internal capital market. Adopting greater international diversification could even improve a firm's intangible assets, so that to create an important value for the firm [12]. Also, the risk and cost of international diversification could be minimized by intelligently internalizing/transferring the value of foreign assets to the firm of the home country [13]. In contrast, [14] document the disadvantages of adopting international diversification upon the difficulties of establishing market synergies between each businesses division. Even, international diversification exposes the firms with a wider range of uncertainties either from the perspectives of the regulations in various markets, the cultural diversity in organizations as well as diverse natural environments [15]. It causes high internal transaction costs for information and coordination.

With respect to industrial diversification, 13,16] documents that the benefits of internalization are only limited to related-industry diversification, of which the core capabilities (e.g. product line knowledge, skills and experience) can only be transferred efficiently to the correlated diversified segments. Even, firms diversifying into related industries require lesser costs; instead, firms diversifying into unrelated industries require a substantial cost to adapt to the new and the unfamiliar business environment. Comparatively, it is said that related industrial diversification has greater benefits from the perspective of economies of scope and scale. In opposite, the internal market efficiency hypothesis [17-18] argues that, due to the heterogeneity of investment options, the firms' resource could only be efficiently allocated to the unrelated diversified segments, rather than related diversified segments. Unrelated industrial diversification also enables the firms to enjoy the low cost of accessing to the other external funds in the firms' portfolio of diversification [19]. As unrelated industrial diversification promotes cheaper cost of capital and optimal investment, [20]demonstrate that the benefits of adopting unrelated industrial diversification are greater than related industrial diversification strategy.

In general, the inconsistency of the effect of diversification on firm performance may be due to the negligence of the market structure [21]. [22] document that the lack of focus on the industryspecific effect towards the diversification strategies, as well as the negligence of the relatedness of the diversified segments with the firms' core businesses would constitute to a biased result obtained. [2] also provide the notion that industry-specific factor could significantly influence the diversification strategies of a firm, from the perspective of risk reduction. By specifically focusing on restaurant industry, [22] is able to account for the nature of the restaurant industry, as well as the nature of the other diversified segment which is highly correlated to the restaurant industry, for instance the foodproduction segment. It is argued that they are correlated in terms of high volume, low profits and low growth in sales. Nonetheless, to-date, limited studies are found focusing on the issue of related and unrelated diversification in the context of hotel industry. 


\section{Methodology}

This study focuses on hotel firms based on Nace Rev. 2 code (hotel and similar accommodation). We focus on the hotel firms from four economies in Asia, namely China, Hong Kong, Malaysia and Singapore. The selected economies have the top tourism receipts in the year 2011. A total of 42 firms is selected in our sample. The financial data for each firm is obtained from Datastream, a division of Thomson Reuter database, across the year 2001-2011. The data on firms' industrial and international diversification is obtained from Osiris, a Bureau van Dijk database. The data is rearranged in panel, resulting in a total of 462 observations in the analysis sample. Fixed effect is applied in the panel regression, to avoid bias results obtained due to the endogeneity problem which has been addressed in firm-level finance studies.

Model 1 is constructed to show the relationship between related/unrelated industrial and international diversification and firm performance, by controlling for the other firm fundamental variables.

$$
\begin{aligned}
& \text { ROA }_{i t}=\alpha_{i t}+\beta_{1} \text { FirmSize }_{i t}+\beta_{2} \text { Leverage }_{i t}+\beta_{3} \text { Tobin }_{i t}+\beta_{4} \text { Dividend }_{i t} \\
& +\beta_{5} \text { DCrisis }_{t}+\beta_{6} \text { relatedIndustrialDiversification }_{i t}+\beta_{7} \text { UnrelatedIndustrialDiversification }_{i t} \\
& +\beta_{8} \text { relatedInternationalDiversification }_{i t}+\beta_{9} \text { UnrelatedInternationalDiversification }_{i t} \\
& +\{\text { Firm_Effect }\}+\varepsilon_{i t}
\end{aligned}
$$

where $\mathrm{ROA}_{\text {it }}$ is the return of assets, a proxy for firm performance. FirmSize is the proxy for firm size, measured by the natural logarithm of total assets, Leverage is the proxy for firm leverage measured by the ratio of total debt to total capital, Tobin Q is the proxy for firm growth opportunity, measured by the ratio of the sum of the equity market value and liabilities book value to the sum of equity book value and liabilities book value. DCrisis is the dummy variable for three crisis events, i.e. 2001 U.S. 911 attacks, 2003 SARS outbreaks, 2008 Financial downturn and 2009 H1N1 disease outbreaks, takes the value of 1 for the year of crisis, and 0 otherwise. We also measure the degree of diversification using entropy measurement, invented by [23], and later is introduced by [24] in diversification research. The formula for entropy measure is shown in the following. Following [25], this study incorporates two aspects of diversification variables, i.e. industrial and international diversification variables in a model.

$$
\text { EntropyDiversificationIndex }=\sum_{i=1}^{N} P_{i} X \ln \left(1 / P_{i}\right)
$$

where $P_{i}$ is the ratio of the ratio of the firm's total sales within $i$ th industry/geographical segment, and $\mathrm{N}$ is the number of the diversified segments. The use of entropy measure enables us to further calculate the degree of diversification from two perspectives, i.e. related and unrelated industrial/international diversification. As the performance of hotel industry is closely related to tourism demand, we consider all of the diversified tourism related industrial segments (e.g. restaurants, travel agency or recreational service provider) of a firm as the related industrial diversification, otherwise, it is considered as unrelated industrial diversification. For instance, if the hotel firm diversifies its business segments into restaurants and travel agency industry segments, we say that the firm diversifies into related industry segments; in other words, the firm has zero degree of unrelated industrial diversification. With respect to international diversification, the firms that diversify its business to the other countries in the Asian region are considered having related international diversification. For instance, a Malaysian hotel firm diversify its business to Indonesia and Singapore which are in the Asian region, we will categorize the firms under the group of related international diversification, while we say that the firms have zero degree of unrelated international diversification. 
Model 2 further tests the moderating effect of board size to the relationship between diversification and firm performance during a crisis period. Two sets of subsample are generated, grouped by the years of crisis and without crisis. Other board's related variables which could have influences towards firm performance are incorporated in model 4. Significant relationship found in the interaction terms implies that board size has significant moderating effect towards the relationship between diversification and firm performance.

$$
\begin{aligned}
& \text { ROA }_{i t}=\alpha_{i t}+\beta_{1} \text { FirmSize }_{i t}+\beta_{2} \text { Leverage }_{i t}+\beta_{3} \text { Tobin }_{i t}+\beta_{4} \text { Dividend }_{i t} \\
& +\beta_{5} \text { DCrisis }_{t}+\beta_{6} \text { BoardSize }_{i t}+\beta_{7} \text { IndepBoard }_{i t}+\beta_{8} \text { BoardMeeti }_{n g}{ }_{\text {it }} \\
& +\beta_{9} \text { BoardOwner ship }_{i t}+\beta_{10} \text { relatedInd ustrialDiv ersificati on }{ }_{i t} \\
& +\beta_{11} \text { UnrelatedI ndustrialD iversifica tion }_{i t}+\beta_{12} \text { relatedInt ernational Diversific ation }_{i t} \\
& +\beta_{13} \text { UnrelateIn ternationa llDiversif ication }_{i t}+\sum_{k=14} \beta_{k}\{\text { Diversific ationVaria bles } * \text { BoardSize }\} \\
& +\{\text { Firm_Effect }\}+\varepsilon_{i t}
\end{aligned}
$$

\section{Data Analysis and Discussion}

Table 1 presents the regression results in this study. The signs of the variables are consistent with our expectation, of which the effects of firm size, Tobin Q and dividend per share are found statistically significant towards firm performance, except for the effect of leverage is shown statistically insignificant. Crisis is significantly and negatively related to firm performance, which is consistent with the findings of [26] and [27]. It indicates that hotel firm performance is susceptible to the crisis events, and it is worthy of in-depth research on the relationship crisis and hotel firm performance.

We find that unrelated industrial diversification is positively and significantly related to firm performance. The result demonstrates that the greater the unrelated industrial diversification, the better the firm performance. Nevertheless, related industrial diversification is shown having a significant negative impact towards firm performance. The findings are different with the study of [28] showing that unrelated industrial diversification reduces firm value while related industrial diversification does not significantly influence firm value. It shows the importance of conducting in-depth research on diversification in specific industry as the individual industry-specific factors could have different implications towards the effect of diversification. The results indicate that the unrelated industrial diversification strategy is the best to be implemented for hotel industry players to minimize the firm risk. With respect to international diversification, diversifying the business to the countries not located within the same geographical region of the focal firm may have significant negative impact towards firm performance. This may be due to the nature of hotel industry which is a service-based industry that is highly required to align the business with the local culture or livelihood in the diversified countries. This may increase the cost of the adaptation, as indicated by [15], and hereby magnify the disadvantage of unrelated international diversification of the hotel firms. However, we find no significant effect of the related international diversification towards firm performance.

Table 1. Regression Results on the Relationship between Crisis, Diversification \& Firm Performance

\begin{tabular}{lll}
\hline & Baseline & Diversification \\
\hline Firm Size & $0.0129^{* *}$ & 0.0073 \\
& $(0.0436)$ & $(0.3129)$ \\
everage & 0.0001 & -0.0009 \\
& $(0.8599)$ & $(0.7122)$ \\
Tobin Q & $0.0312^{* *}$ & $0.0156^{* *}$ \\
Dividend & $(0.0405)$ & $(0.0102)$ \\
& $0.4743^{*}$ & $0.5203^{* *}$ \\
DCrisis & $(0.0972)$ & $(0.0410)$ \\
\hline
\end{tabular}




\begin{tabular}{lll}
\hline & $(0.0000)$ & $(0.0001)$ \\
Related Industrial Diversification & & $-0.0450^{*}$ \\
& & $(0.0899)$ \\
Unrelated Industrial Diversification & & $0.0214^{*}$ \\
& & $(0.0775)$ \\
Related International Diversification & & 0.0114 \\
& & $(0.6093)$ \\
Unrelated International Diversification & & $-0.0674^{* *}$ \\
& & $(0.0120)$ \\
Constant & $-0.1662 * *$ & -0.0675 \\
& $(0.0472)$ & $(0.4956)$ \\
Observations & & 343 \\
Adjusted R2 & 439 & 0.0938 \\
\hline
\end{tabular}

Table 2 further tests the moderating effect of board size towards the effect of diversification on firm performance. The results show that during a crisis period, board size significantly and negatively moderates the effect of unrelated industrial/international diversification on firm performance. However, board size significantly and positively moderates the effect of related international diversification on firm performance in the crisis period. The significance moderating effect found only in the crisis period implies that turbulent circumstances could maximize the mobilization of board power in decision making [29], of which the results demonstrate that the board of directors tends to employ the benefits of diversification to sustain the firm performance in the crisis period. However, the research issue of board size demonstrates that larger board size with greater human capital does not necessarily bring positive influence to the effect of diversification, as larger board size may have communication problem in a topic-wide discussion, or discussion uncovering a wider area of scope, particularly in the critical crisis period where time is limited for responses. Nonetheless, it gives the notion to the existing literature that the board of directors implies a link to the relationship between diversification and firm performance only in the crisis period.

Table 2. Regression Results on the Moderating Effect of Board Size to the Relationship between Diversification and Firm Performance

\begin{tabular}{|c|c|c|c|c|}
\hline \multirow[b]{2}{*}{ Related Industrial Diversification } & \multicolumn{2}{|c|}{ Dummy of crisis $=1$} & \multicolumn{2}{|c|}{ Dummy of crisis $=0$} \\
\hline & $\begin{array}{l}-0.1233 \\
(0.4413)\end{array}$ & $\begin{array}{l}-0.0662^{*} \\
(0.0991)\end{array}$ & $\begin{array}{l}-0.1677^{*} \\
(0.0795)\end{array}$ & $\begin{array}{l}-0.0471 \\
(0.3044)\end{array}$ \\
\hline Unrelated Industrial Diversification & $\begin{array}{l}0.2817 * * \\
(0.0155)\end{array}$ & $\begin{array}{l}0.0557 * * \\
(0.0331)\end{array}$ & $\begin{array}{l}-0.0386 \\
(0.4729)\end{array}$ & $\begin{array}{l}-0.0105 \\
(0.6259)\end{array}$ \\
\hline Related International Diversification & $\begin{array}{l}-0.0672 \\
(0.2214)\end{array}$ & $\begin{array}{l}-0.7567 * * \\
(0.0136)\end{array}$ & $\begin{array}{l}0.0282 \\
(0.4365)\end{array}$ & $\begin{array}{l}0.0082 \\
(0.9084)\end{array}$ \\
\hline Unrelated International Diversification & $\begin{array}{l}-0.0943 \\
(0.2148)\end{array}$ & $\begin{array}{l}2.5256^{*} \\
(0.0753)\end{array}$ & $\begin{array}{c}-0.0663^{*} \\
(0.0648)\end{array}$ & $\begin{array}{c}-0.1239^{*} \\
(0.0599)\end{array}$ \\
\hline Related Industrial Diversification*Board Size & $\begin{array}{l}0.0030 \\
(0.8284)\end{array}$ & & $\begin{array}{l}0.0128 * \\
(0.0980)\end{array}$ & \\
\hline Unrelated Industrial Diversification*Board Size & $\begin{array}{l}-0.0228 * \\
(0.0582)\end{array}$ & & $\begin{array}{l}0.0033 \\
(0.5154)\end{array}$ & \\
\hline Related International Diversification*Board Size & & $\begin{array}{l}0.0594 * * \\
(0.0204)\end{array}$ & & $\begin{array}{l}0.002 \\
(0.7656)\end{array}$ \\
\hline Unrelated International Diversification*Board Size & & $\begin{array}{l}-0.2869^{*} \\
(0.0671)\end{array}$ & & $\begin{array}{l}0.007 \\
(0.1522)\end{array}$ \\
\hline Observations & 80 & 80 & 204 & 204 \\
\hline Adjusted R2 & 0.3566 & 0.4663 & 0.0261 & 0.0135 \\
\hline
\end{tabular}

Note: the coefficient of the control variables are not reported in this table 


\section{Conclusion and Implications}

Our findings imply that the premium of risk minimization from diversification is more significant to influence firm performance, rather than to establish the market synergy from diversification. It gives us the notion that hotel firms should diversify its business into the other industry segments, and the nature of the diversified industry segment should not correlate to the tourism-related activities. Also, hotel firms are not encouraged to diversify to the other markets, especially to the markets father away from the region. It may be due to the nature of hotel business which is in service-based industry, of which it requires higher cost of adaptation to the environment of the other country in terms of cultural and organization diversity, climate change, etc. This study further finds that the board of directors, the ultimate decision makers in a firm, implies a significant link to the relationship between diversification and firm performance, but the effect is only restricted to the crisis period. It gives us the notion that board of directors attempts to exploit the other diversified segments to sustain the firm performance during a crisis period. Despite having greater human capital from larger board size, our findings instead, are parallel with the notion of [30] documenting that larger board size is less effective and easier to be controlled by chief executive officer, and it gives rise to the difficulty of expressing their ideas and opinions in the board meeting, leading to poor decision making processes [13] in a crisis period. It further consolidates the previous studies of [30] and [31] that larger board size is less effective, especially when dealing with wider scope of discussion on the unrelated business division issues.

\section{Acknowledgements}

The authors would like to extend their appreciation to the Universiti Sains Malaysia for the Research University Grant entitled "Tourism Planning” [grant number 1001/PTS/8660013] that made this study and paper possible.

\section{References}

1. M. Lubatkin, H. O’Neill, Merger strategies and capital market risk. Academy of Management Journal, 30, 4, 665-684 (1987)

2. R. Bettis, W. Hall, Diversification strategy, accounting determined risk, and accounting determined return. Academy of Management Journal, 25, 2, 254-264 (1982)

3. C. Montgomery, H. Singh, Diversification strategy and systematic risk. Strategic Management Journal, 5, 2, 181-191 (1984)

4. M. A. Hitt, L. Bierman, K. Shimizu, R. Kochhar, Direct and moderating effects of human capital on strategy and performance in professional service firms: a resource-based perspective. Academy of Management Journal, 44, 1, 13-28 (2001)

5. Y. Kor, H. Leblebici, How Do Interdependencies Among Human-Capital Deployment, Development, And Diversification Strategies Affect Firms' Financial Performance? Strategic 44. Management Journal, 26, 967-985 (2005)

6. S. Sciascia, P. Mazzola, J.H. Astrachan, T,M. Pieper, The role of family ownership in international entrepreneurship: Exploring nonlinear effects. Small Business Economics, 38, 15-31 (2012)

7. L. R. Gomez-Mejia, The role of human resources strategy in export performance: A longitudinal study. Strategic Management Journal, 9, 493-505 (1988)

8. P. Westhead, M. Wright, D. Ucbarasan, Internationalization of new and small firms: A resource based-view. Journal of Business Venturing, 16, 333-358 (2001)

9. R. Rumelt, Diversification strategy and profitability. Strategic Management Journal, 3, 4, 359-369 (1982)

10. A. Pye, Corporate directing: Governing, strategising and leading inaction. Corporate Governance, 10, 153-162 (2002) 
11. T. Khanna, P. Krishna, Is group affiliation profitable in emerging market? An analysis of diversified Indian business groups. Working paper, Harvard Business School (1998).

12. J.H. Dunning, A.M. Rugman, The influence of Hymer's dissertation on the theory of foreign direct investment. American Economic Review, 75, 2, 228-232 (1985)

13. R.E. Caves, Industrial corporations: the industrial economics of foreign investment. Economica, 38, 1-27 (1971)

14. P.S. Davis, R.B. Robinson, J.A. Pearce, S.H. Park, Business Unit Relatedness and Performance: A Look at the Pulp and Paper Industry. Strategic Management Journal, 13, 349-362 (1992)

15. P.J. Buckley, R. Strange, The governance of the multinational enterprise: Insights from internalization theory. Journal of Management Studies, 48, 2, 460-470 (2011)

16. R. Rumelt, Strategy, Structure, and Economic Performance. Harvard University Press, Cambridge, MA (1974).

17. W. G. Lewellen, A Pure Financial Rationale for the Conglomerate Merger, Journal of Finance, 26, 521-537 (1971)

18. F. Scherer, Industrial arket Structure and Economic Performance. Rand McNally, Chicago, IL (1980).

19. M. Margaret, M. Paul, R. John, Organizational prospects, influence costs, and ownership changes. Journal of Economics and Management Strategy, 1, 9-35 (1992)

20. C. Hill, S. Snell, External control, corporate strategy, and firm performance in research-intensive industries. Strategic Management Journal, 9, 6, 577-590 (1988)

21. H. Christensen, C. Montgomery, Corporate economic performance: Diversification strategy versus market structure. Strategic Management Journal, 2, 4, 327-343 (1981)

22. K. Park, S.C. Jang, Effect of diversification on firm performance: Application of the entropy measure. International Journal of Hospitality Management, 31, 218-228 (2012)

23. L. Boltzmann, Entgegnung auf die warmetheoretischen Betrachtungen des Hrn. E. Zermelo. Annalen der Physik, 293, 773-784 (1896)

24. A. Jacquemin, C. Berry, Entropy measure of diversification and corporate growth. The Journal of Industrial Economics, 27, 4, 359-369 (1979)

25. G. Bodnar, C. Tang, J. Weintrop, Both sides of corporate diversification: the value impacts of geographic and industrial diversification. Johns Hopkins University Working Paper (1999).

26. M. H. Chen, W. G. Kim, H. J. Kim, The impact of macroeconomic and non-macroeconomic forces on hotel stock returns. International Journal of Hospitality Management, 24, 243-258 (2005)

27. M. H. Chen, S. C. Jang, W. G. Kim, The impact of SARS outbreak on Taiwanese hotel stock returns: An event study approach. International Journal of Hospitality Management, 26, 1, 200212 (2007)

28. S.C. Bae, T.H. Kwon, J.W. Lee, Does corporate diversification by business groups create value? Evidence from Korean chaebols. Pacific-Basin Finance Journal, 19, 535-553 (2011)

29. B.E. Hermalin, M.S. Weisbach, Endogenously chosen boards of directors and their monitoring of the CEO. The American Economic Review, 88, 96-118 (1998)

30. M. C. Jensen, The modern industrial revolution, exit, and the failure of internal control systems. Journal of Finance, 48, 3, 831-880 (1993)

31. M. Lipton, J. W. Lorsch, A modest proposal for improved corporate governance. Business Law, 48, 1, 59-77 (1992) 